\title{
EFFECT OF ADDITION OF ANISE, CLOVE AND THYME ESSENTIAL OILS ON BARKI LAMBS PERFORMANCE, DIGESTIBILITY, RUMEN FERMENTATION, CARCASS CHARACTERISTICS AND INTRAMUSCULAR FATTY ACIDS.
}

\author{
Abeer M. El-Essawy ${ }^{1}$; Ahlam R. Abdou' ${ }^{1}$;.M. Khattab ${ }^{2}$ and A.M. Abdel-Wahed ${ }^{1}$ \\ IAnimal and Poultry Nutrition Department, Desert Research Center, El-Matarya, Cairo, Egypt. \\ ${ }^{2}$ Department of Animal and Fish Production, Faculty of Desert and Environmental Agriculture, \\ Matrouh University,51744 Matrouh, Egypt.
}

(Received 2/10/2019, accepted 19/11/2019)

\section{SUMMARY}

$\mathrm{R}$ ecently, some plants essential oils (EO) are used as natural feed additives for ruminants because their major bioactive compounds have antimicrobial properties that can be effective against undesirable rumen microbes. In addition, EO have not an adverse effect either on animal or human health and environment. This work was carried out to evaluate the effect of natural additives as essential oils addition on animal performance, feed intake, apparent digestibility, carcass characteristics, chemical composition and fatty acids profile of longissimus lumborum muscle of Barki lambs. Twenty weaned male Barki lambs ( $19.72 \pm 2.09) \mathrm{kg} \mathrm{BW}, 3$ months old were randomly assigned in one of four diet groups, 5 animals each, were received the same basal diet, $(50 \%$ berseem hay, $\mathrm{BH}$, and $50 \%$ concentrate feed mixture). All experimental animals were kept in individual pens for 195 days for fattening trial and 15 days for digestibility trial. At the end of the experiment all lambs were slaughtered for carcass characteristics evaluation and meat fatty acids (FAs) profile determination. The control lambs were fed their basal diet without EO supply. The other three groups were orally given, by syringe, one of the three tested EO before morning feeding as follow: the basal diet plus $2 \mathrm{ml} / \mathrm{day} / \mathrm{lamb}$ of anise EO (Anise group), $2 \mathrm{ml} / \mathrm{day}$ /lamb clove EO (Clove group) or $2 \mathrm{ml} /$ day/lamb thyme EO (Thyme group). According to the results, the experimental EO had no significant effects on nutrients intake, lamb's performance (final body weight, average daily gain and feed conversion ratio) $(\mathrm{P}>0.05)$. Clove EO improved dry matter (DM), organic matter $(\mathrm{OM})$, crude protein $(\mathrm{CP})$, ether extract $(\mathrm{EE})$, acid detergent fiber $(\mathrm{ADF})$ digestibility $(\mathrm{P}<0.05)$ and nitrogen balance\% of intake $(\mathrm{P}<0.05)$. Ruminal parameters showed higher ruminal ammonia with thyme EO supply $(\mathrm{P}<0.05)$. Most of carcass characteristics were not affected by EO addition but lambs of clove group showed a significant increase in weight of feet $(\mathrm{P}<0.05)$, full $(\mathrm{P}<0.01)$ and empty $(\mathrm{P}<0.05)$ digestive tract, tail fat $(\mathrm{P}<0.01)$ and liver $(\mathrm{P}<0.05)$ compared with control lambs. Some blood plasma metabolites were affected by EO where plasma createnine and low-density lipoprotein (LDL) were increased $(\mathrm{P}<0.05)$ in thyme group however, total lipids and cholesterol increased in clove group. Fatty acids content of longissimus lumborum muscle was slightly affected by addition of EO where palmitoleic (C16:1n-7) was increased and arachidonic acids $(\mathrm{C} 20: 4 \mathrm{n}-6)$ was decreased $(\mathrm{P}<0.05)$ in meat of lambs fed clove. Also, clove inclusion in lambs diet increased monounsaturated fatty acids (MUFA) deposition in their meat $(\mathrm{P}<0.05)$. Overall, addition of anise, clove or thyme EO to lambs' diets may not have the potential to improve animal growth performance, blood metabolites and meat chemical composition. Clove EO has a considerable positive effect on nutrients digestibility and improve carcass characteristics, meat FA profile. Further research are needed with higher concentrations of EO for longer duration of supply.

Keywords: essential oil, lambs, carcass, blood plasma, fatty acid profile, meat.

\section{INTRODUCTION}

The use of natural additives has reported as an essential principle of healthy nutrition. The ban on antibiotics use in animal nutrition as feed additives due to its residual effect found in milk and meat products and the increased awareness of the consumers about the health hazards occurs due to the use of antibiotics in animal nutrition triggered searching for natural and safe feed additives (Khamisabadi et. al. 2016) because they have health benefits on animals when used as feed additives in animal nutrition. 
The evaluation of EO for antimicrobial, antifungal and antioxidant properties has been conducted by humans in traditional medicine and there were much research on the use of plant extracts and EO in animal production all over the world (Khateri et. al., 2017). Plants essential oils (EO) from clove, cinnamon and thyme were more favorable, due to their valuable effects on rumen fermentation such as decrease in methane emissions and ammonia nitrogen $(\mathrm{N})$ concentration and an increase in propionate to acetate ratio (Jahani-Azizabadi et. al., 2011). Thyme (Thymus vulgaris L) is a medicinal herb in the Lamiaceae family, has special functions such as antiseptic, antimicrobial and antioxidant (Sengul et. al., 2008). Therefore, the objective of this study was to determine whether these essential oils can be used as feed additives in fattening lambs to improve animal performance, yield and quality of meat through measuring feed intake, growth rate, blood metabolites and carcass characteristics.

\section{MATERIALS AND METHODS}

The present study was conducted at Maryout Research Station, Desert Research Center, Ministry of Agriculture, $35 \mathrm{Km}$ south of Alexandria, Egypt

\section{Animals, diets and experimental procedures:}

\section{Fattening trial:}

After weaning lambs at 3 months old on average, twenty male growing lambs with average live body weight of $19.72 \pm 2.09 \mathrm{~kg}$ body weight were used. The study lasted for 210 days including 195 days for fattening and 15 days for digestibility trials. Lambs were randomly divided into four homogenous groups ( 5 animals each). Lambs of each group were housed in a concrete pen $(5 \mathrm{~m} \times 5 \mathrm{~m})$ and randomly assigned to receive one of four tested diets. Animals of the control group were fed on the basal diet (without essential oil supplement) which consisted of $50 \%$ concentrate feed mixture (CFM) and $50 \%$ Berseem hay $(\mathrm{BH})$. The CFM composed of $17 \%$ soybean meal, $52.5 \%$ yellow corn, $28 \%$ wheat bran, $0.9 \%$ salt, and $1.1 \%$ limestone 0.5 vitamin mineral premix. The other three groups were fed on the same basal diet with supplementation of one of the three tested EO as follow: Control diet plus $2 \mathrm{ml} / \mathrm{h} /$ day of Anise (Pimpinella anisum, AEO, group) or plus $2 \mathrm{ml} / \mathrm{h}$ /day of Clove (Syzygium aromaticum, CEO, group) or plus $2 \mathrm{ml} / \mathrm{h} /$ day of Thyme (Thymus vulgaris, TEO, group).

Feeding requirements were calculated according to the recommended feeding standards of NRC (2007). The amount of ration was daily weighed and offered to the animals and changed biweekly depending on the live body weight changes till the end of the experimental period. The rations were offered twice a day for all groups. The CFM was offered daily at 8:00 am while BH was offered at 12:00 $\mathrm{pm}$, as group feeding. Free fresh clean tap water was allowed free - choice drinking once daily after the morning feeding. The daily feed intake was recorded, and the orts were determined next morning. The chemical composition of the basal diet is presented in Table, (1). The lambs were weighed at 15 day intervals throughout the study just before morning feeding to calculate the average daily gain (ADG) and feed conversion (FC: $\mathrm{g}$ of BW gain $/ \mathrm{kg}$ of feed). Feed intake, utilization as well as daily live weight gains were recorded.

Table (1): Nutrient composition of the basal diet (on DM basis \%)

\begin{tabular}{lcc}
\hline Item & Concentrate feed mixture & Berseem hay \\
\hline Dry matter & 92.18 & 90.66 \\
Organic matter & 96.23 & 85.57 \\
Crude protein & 14.23 & 13.12 \\
Ether extract & 3.88 & 3.47 \\
Ash & 3.77 & 14.43 \\
Neutral detergent fiber & 30.56 & 56.03 \\
Acid detergent fiber & 13.05 & 45.61 \\
\hline The CFM composed of 17 soybean meal, 52.5\% yellow corn, 28\% wheat bran, 0.9\% salt, 1.1\% limestone 0.5 Vitamin &
\end{tabular}

\section{Digestibility trial:}

At the end of fattening period, 4 animals from each group were subjected to digestibility trial to determine nutrient digestibility coefficients. Animals were kept individually in metabolic cages for 15 


\section{El-Essawy et al.}

days. The first 5 days were for adaptation period followed by 5 days for sample collection. Lambs were fed the same diets with the same additives as in fattening trial. Drinking water consumption was determined for each animal daily. The urine and fecal samples were collected, measured or weighed daily and $10 \%$ sample as a representative sample were collected and stored (urine) or dried (feces) for further analysis. Diet apparent digestibility and animal $\mathrm{N}$ balance were measured at the end of period.

\section{Slaughter and carcass measurements}

At the end of the study, on day 210 all of the lambs from the four fattening groups were starved for 12 $\mathrm{h}$, weighed and slaughtered in the slaughter house of the station. After complete evisceration and dressing, the carcasses were weighed (the hot carcass weight). Non-carcass components, gastrointestinal tracts and viscera were separately weighted. Selected internal organs (liver, heart, and kidneys) were weighted. The contents of the digestive tract were removed, and their weight was subtracted from the slaughter live weight to obtain the empty body weight $(\mathrm{EW})$. Dressing percentage was estimated as the percentage of carcass weight $(\mathrm{CW})$ relative to the $\mathrm{EW}$ and as a percentage of the hot carcass relative to the EW. Carcasses were chilled at $4^{\circ} \mathrm{C}$ for $24 \mathrm{~h}$ and then weighed (the cold carcass). The cold carcass was split into two symmetrical parts along the backbone. Simple dissection of their right halves was carried out. The samples of longissimus lumborum muscle ( $\mathrm{Ll}$ ) from the 10th to 13th rib were taken for chemical composition and FA profile. Muscle samples were minced, packed into polyethylene bags and stored at $30^{\circ} \mathrm{C}$ until analysis. To obtain the (Ll) area, the exposed area of the ( $\left.\mathrm{Ll}\right)$ muscle was drawn on tracing paper, and measured three times with a digital planimeter koizumi placom (kp-82) to the nearest $\mathrm{cm}^{2}$. The values obtained were used to calculate the mean of the $\mathrm{Ll}$ area. Fatty acids profile was determined by using High Pressure Liquid Chromatography (HPLC) according to AOAC (2007).

\section{Laboratory analytical methods:}

\section{Chemical analysis}

The proximate chemical analysis was conducted on representative samples of feedstuffs, orts, feces, muscles, and nitrogen in urine samples according to standard methods of AOAC (2007). Neutral detergent fiber (NDF), acid detergent fiber (ADF) were determined by using the automated ANKOM fiber analyzer as described by Goering and Van Soest (1970).

\section{Analysis of feed additives (essential oils)}

Essential oils were provided by Natural oil extraction and Pressing unit, National Research Center, Dokki - Giza, Egypt). Essential oils analysis was performed using gas chromatography-mass spectrometry instrument stands at the Department of Medicinal and Aromatic Plants Research, National Research Center according to El-Gendy et. al. (2017) as previously mentioned in El -Essawy et. al. (2019). Compounds identified in the studied essential oils and their active components as percentage (\%) are listed in Table, (2).

\section{Ruminal liquor analysis}

On the last day of the digestibility trial, rumen liquor was withdrawn by stomach tube from all lambs before morning feeding. The $\mathrm{pH}$ of rumen liquor was immediately recorded using digital $\mathrm{pH}$ meter, Gallen Kamp pH Stick pH K-120 - B. The entire contents were squeezed through four layers of cheesecloth and kept frozen until analyzed for ammonia - nitrogen $\left(\mathrm{NH}_{3}-\mathrm{N}\right)$ (AOAC, 2007) and total volatile fatty acids (TVFA's) Warner (1964).

\section{Biochemical blood analysis}

At the end of the digestibility trial blood samples were collected from all lambs in each group used in the digestibility trial via jugular vein in a heparinized tubes before morning feeding. All samples were centrifuged at $4.000 \mathrm{rpm}$ for 15 minutes and the collected plasma was stored at $-20^{\circ} \mathrm{C}$ for subsequent analysis. Plasma concentrations of total protein, albumin, (globulin was obtained by subtracting the total proteins values from the albumin values), blood urea-N, creatinine, total cholesterol (TC), triglycerides (TG), high density lipoprotein (HDL), low density lipoprotein (LDL), total lipids (TL), alanine amino transferase (ALT), aspartate amino transferase (AST) and total antioxidant capacity (TAC) were determined using Bio diagnostic laboratory kits.

\section{Statistical analysis}

Analysis of variance (ANOVA) was used to test the obtained data using the general linear modeling procedure (SAS, 2000). Duncan (1955) Multiple Comparison Tests were applied with the $\mathrm{P}<0.05$ value for significance. 
Table (2): The main active components of Anise, Clove and Thymol essential oils

\begin{tabular}{|c|c|c|c|}
\hline The plant EO & $\mathrm{R} \mathrm{T}$ & Relative percentage $(\%)$ & Main components \\
\hline \multicolumn{4}{|c|}{ Anise (Pimpinella anisum) } \\
\hline & 7.45 & 0.17 & $\beta$-Terpinyl acetate \\
\hline & 14.22 & 1.81 & p-Allylanisole \\
\hline & 16.21 & 3.24 & 1-Carvone \\
\hline & 16.58 & 3.35 & p-Allylanisole \\
\hline & 17 & 1.64 & Anisaldehyde \\
\hline & 18.32 & 81.86 & Trans-anethole \\
\hline & 20.52 & 0.41 & 1,2-DIACETIN \\
\hline & 22.38 & 0.3 & p-Anisylacetone \\
\hline & 24.28 & 0.26 & $\alpha$-Himachalene \\
\hline & 25.49 & 2.27 & Humulen-(v1) \\
\hline & 25.7 & 0.88 & $\alpha$-Curcumen \\
\hline & 26.22 & 0.68 & Zingiberene \\
\hline & 26.33 & 0.81 & $\beta$-Himachalene \\
\hline & 26.71 & 0.42 & $\beta$-Bisabolene \\
\hline & 38.9 & 1.9 & Allocryptopine \\
\hline \multicolumn{4}{|c|}{ Clove (Syzygium aromaticum) } \\
\hline & 16.75 & 0.12 & Acetin, mono \\
\hline & 18.39 & 0.03 & Thymol \\
\hline & 19 & 0.02 & Dimethylbenzyl carbinyl acetate \\
\hline & 21.17 & 99.07 & Eugenol \\
\hline & 24.14 & 0.03 & Diacetin monopropanoate \\
\hline & 25.15 & 0.05 & Isoeugenol \\
\hline & 27.56 & 0.02 & Eugenol acetate \\
\hline & 47.16 & 0.19 & 1-Docosanol \\
\hline & 58.24 & 0.03 & Squalene \\
\hline \multicolumn{4}{|c|}{ Thyme (Thymus vulgaris) } \\
\hline & 4.63 & 7.52 & $\alpha$-Pinene \\
\hline & 5.83 & 11.21 & $\beta$-Pinene \\
\hline & 6.76 & 0.34 & $\alpha$-Phellandrene \\
\hline & 7.09 & 0.54 & (+)-2-CARENE \\
\hline & 7.34 & 24.3 & p-Cymene \\
\hline & 8.02 & 0.57 & Benzyl Alcohol \\
\hline & 8.44 & 1.06 & $\gamma$-Terpinene \\
\hline & 9.46 & 0.64 & Terpinolene \\
\hline & 10.05 & 2.84 & L-linalool \\
\hline & 13.07 & 0.61 & endo-Borneol \\
\hline & 13.36 & 1.24 & 4-Terpineol \\
\hline & 14.21 & 1.74 & Anethole \\
\hline & 15.34 & 0.42 & O-Methylthymol \\
\hline & 15.71 & 0.28 & Carvacrol methyl ether \\
\hline & 18.49 & 40.59 & Thymol \\
\hline & 18.68 & 1.9 & Carvacrol \\
\hline & 20.54 & 3.49 & Glycerol 1,2-diacetate \\
\hline & 23.57 & 0.48 & $\alpha$-Bergamotene \\
\hline & 26.9 & 0.24 & $\gamma$-CADINENE \\
\hline
\end{tabular}

Retention time $(R T)$ is a measure of the time taken for a solute to pass through a chromatography column. It is calculated as the time from injection to detection. The RT for a compound is not fixed as many factors can influence it even if the same GC and column are used.

\section{RESULTS AND DISCUSSION}

\section{Feed intake, digestibility and lamb performance:}

Data of nutrient intake and growth performance are presented in Table (3) and Table (4), respectively. 
Table (3): Effect of supplementation of Anise, Clove and Thyme oils to lamb diets on nutrient intake and digestibility.

\begin{tabular}{cccccc}
\hline Item & \multicolumn{4}{c}{ Treatment $^{1}$} & \multirow{2}{*}{ SEM $^{2}$} \\
\cline { 2 - 4 } & Control & Anise & Clove & Thyme & \\
\hline Nutrient intake, g/d & 1433 & 1408 & 1406 & 1431 & 21.67 \\
DM & 1307 & 1285 & 1282 & 1305 & 18.18 \\
OM & 196.9 & 193.6 & 193.2 & 196.73 & 2.88 \\
CP & 52.79 & 51.93 & 51.68 & 52.73 & 0.761 \\
EE & 611.2 & 598.7 & 602.25 & 612.1 & 11.58 \\
NDF & 408.7 & 398.99 & 403.94 & 410.08 & 9.22 \\
ADF & & & & \\
Digestibility, \% & $70.77^{\mathrm{ab}}$ & $71.92^{\mathrm{ab}}$ & $73.18^{\mathrm{a}}$ & $68.5^{\mathrm{b}}$ & 1.35 \\
DM & $72.44^{\mathrm{ab}}$ & $73.44^{\mathrm{ab}}$ & $75.27^{\mathrm{a}}$ & $70.50^{\mathrm{b}}$ & 1.25 \\
OM & $69.42^{\mathrm{ab}}$ & $70.76^{\mathrm{ab}}$ & $73.17^{\mathrm{a}}$ & $67.43^{\mathrm{b}}$ & 1.51 \\
CP & $69.54^{\mathrm{b}}$ & $73.70^{\mathrm{ab}}$ & $76.61^{\mathrm{a}}$ & $72.71^{\mathrm{ab}}$ & 1.29 \\
EE & 59.16 & 58.30 & 62.17 & 58.81 & 1.75 \\
NDF & $47.81^{\mathrm{a}}$ & $45.45^{\mathrm{a}}$ & $49.60^{\mathrm{a}}$ & $36.26^{\mathrm{b}}$ & 2.66 \\
ADF & & & & & \\
\hline
\end{tabular}

${ }^{I}$ Control, basal diet without oil supplement; basal diet with Anise oil supplement; basal diet with clove oil supplement and basal diet with Thyme oil supplement, ${ }^{2}$ Standard error of the means.

${ }^{a-b}$ Means within a row with different superscripts are significantly different $(P<0.05)$.

Table (4). Effect of supplementation of Anise, Clove and Thyme oils on lamb's performance

\begin{tabular}{|l|c|c|c|c|c|c|}
\hline \multirow{2}{*}{ Item } & \multicolumn{4}{|c|}{ Treatment $^{1}$} & \multirow{2}{*}{ SEM $^{2}$} \\
\cline { 2 - 6 } & Control & Anise & Clove & Thyme & 2.09 \\
\hline Initial body weight, $\mathrm{kg}$ & 20.05 & 19.51 & 19.53 & 19.80 & 3.51 \\
\hline Final body weight, kg & 55.37 & 54.95 & 55.82 & 54.37 & 9.16 \\
\hline Average daily gain, g/ d & 168.21 & 168.8 & 172.8 & 164.6 & 1.24 & 0.905 \\
\hline Average daily feed intake, $\mathrm{kg} / \mathrm{d}$ & 1.26 & 1.24 & 1.25 & 1.24 & 0.368 \\
\hline Feed conversion ratio, $\mathrm{kg} / \mathrm{kg}$ & 7.53 & 7.53 & 7.26 & 7.59 & 0.36 \\
\hline
\end{tabular}

${ }^{I}$ Control, basal diet without oil supplement; basal diet with Anise oil supplement; basal diet with clove oil supplement and basal diet with Thyme oil supplement; ${ }^{2}$ Standard error of the means.

Unfortunately, the desired object of adding EO as additives to increase feed intake by stimulating appetite was not confirmed. Dry matter (DM) and nutrient intake were not influenced (P>0.05) by EO, which agree with Fandino et. al. (2008) with anise EO, Chowdhury et. al. (2018) with clove in Black Bengal goats, El-Essawy et. al. (2019) in ewes with the same types of EO. Vakili et. al.(2013) found that thyme and cinnamon EO had no effect on DMI and performance of the growing calves. The clove EO addition increased DM, OM, CP, EE and ADF $(\mathrm{P}<0.05)$ digestibilities (table 3), which agree with ElEssawy et. al. (2019) with ewes and they attributed this improvement in digestibility to the phenolic nature of eugenol and it's potency in stimulating bacteria involved in feed digestion. Moreover, Williams et. al. (2018) found that the effect of EO such as thymol, eugenol and others on the efficiency of the utilization of the ingested nitrogen is due to inhibition of the growth and activity of certain microorganisms. Indeed, EO rich in thymol affects proteolysis in the rumen due to it's toxicity to certain species of microorganisms present in rumen, inhibiting the degradation of fibers (Cieslak et. al., 2013). However, Moura et. al. (2017) observed no differences in nutrients intake between lambs fed copaiba EO and monensin. As shown in Table (4), the final weight of lambs, average daily gain (ADG), average daily feed intake or the feed conversion ratio were not affected during the entire study. So, addition of EO to the diet in fattening period had no adverse effects on growth performance when compared with lambs fed control diet. Similar results were recorded on incorporation of a mixture of EO (thymol, eugenol, vanillin and limonene) in beef cattle diet (Benchaar et. al., 2006), three encapsulated EO in sheep diet (Lin et. al., 2013), carvacrol and /or thymol in lambs diet (Biricik et. al., 2016). Other studies inconsistent with the present findings and found that nutrients digestibility were not influenced neither by addition of either essential oils active compounds in sheep diet (Lin et. al., 2013), or addition of EO complex to cows (Santos et. al., 2010). 


\section{Nitrogen retention:}

The nitrogen intake was not affected by addition of EO (Table 5) while the nitrogen excretion, nitrogen balance and utilization were significantly affected by dietary additives $(\mathrm{P}<0.05)$. It is clear that clove EO fed lambs showed the minimum loss of $\mathrm{N}$ and consequently resulted in highest $\mathrm{N}$ balance and utilization. Dijkstra et. al. (2013) explained that clove increased N - retention due to the higher level of active phenolic components. Also, Chowdhury et. al. (2018) agreed with the present results and indicated that clove can reduce $\mathrm{N}$ wastage and increase $\mathrm{N}$ retention in small ruminants. On the other hand, thyme addition to lambs resulted in opposite trend of clove addition. El-Essawy et. al. (2019) consistent with the current results with the same EO in Barki ewes. The higher nitrogen retention is resulted in response to lower nitrogen excretion (table 5) and higher nitrogen digestibility (table 4). Similarly, Smeti et. al. (2015) reported higher nitrogen retention by rosemary supply in ewes and they attributed their findings to protein protection against ruminal degradation (Newbold et. al., 2004) that reducing the nitrogen losses (Terril et. al., 1992).

Table (5) Nitrogen utilization of the experimental rations fed to experimental lambs.

\begin{tabular}{lccccc}
\hline \multirow{2}{*}{ Item } & \multicolumn{2}{c}{ Treatment $^{1}$} & \multicolumn{2}{c}{ SEM $^{2}$} \\
\cline { 2 - 5 } & Control & Anise & Clove & Thyme & 0.461 \\
Nitrogen intake g/head/day & 31.50 & 30.98 & 30.91 & 31.47 & 0.779 \\
Total excretion g/head/day & $23.89^{\mathrm{ab}}$ & $23.13^{\mathrm{ab}}$ & $22.14^{\mathrm{b}}$ & $25.57^{\mathrm{a}}$ & 0.851 \\
Nitrogen balance (NB) g/day & $7.61^{\mathrm{ab}}$ & $7.85^{\mathrm{ab}}$ & $8.77^{\mathrm{a}}$ & $5.90^{\mathrm{b}}$ & 2.56 \\
Nitrogen balance \% of intake & $24.10^{\mathrm{ab}}$ & $25.30^{\mathrm{ab}}$ & $28.34^{\mathrm{a}}$ & $18.72^{\mathrm{b}}$ & 2.56 .25 \\
N-utilization \% of digested & $34.72^{\mathrm{ab}}$ & $35.53^{\mathrm{ab}}$ & $38.73^{\mathrm{a}}$ & $27.41^{\mathrm{b}}$ & 3.25 \\
\hline
\end{tabular}

${ }^{1}$ Control, basal diet without oil supplement; basal diet with Anise oil supplement; basal diet with Clove oil supplement and basal diet with Thyme oil supplement; ${ }^{2}$ Standard error of the means.

${ }^{a-b}$ Means within a row with different superscripts are significantly different $(P<0.05)$.

\section{Ruminal fermentation parameters:}

The ruminal $\mathrm{pH}$ and total volatile fatty acids (TVFA) both were not influenced by adding EO (Table 6). Ammonia nitrogen $\left(\mathrm{NH}_{3}-\mathrm{N}\right)$ concentration was increased significantly $(\mathrm{P}<0.05)$ in the three EO added treatments. Kim et al. (2013) reported that EO affects the rumen microbial activity and consequently alters ruminal fermentation. The increased ammonia concentration in the present study agreed with those obtained by El-Essawy et al. (2019) who used the same EO in ewes and Cardozo et al. (2004) who emphasized that anise extract stimulated peptidolysis and deamination and as a consequence $\mathrm{NH}_{3}-\mathrm{N}$ accumulated. EO had variable impacts on ruminal $\mathrm{NH} 3-\mathrm{N}$ concentration in different studies. Previous researches suggesting that EO increased ruminal ammonia (Tekippe et. al., 2011), others reported that there were no effects (Vakili et. al. 2013) with thyme and cinnamon EO and Chaves et. al. (2008a) with carvacrol or cinnamaldehyde or there were a reduction in ammonia concentration (Lin et al . 2013).

Table (6): Effect of supplementation of Anise, Clove and Thyme and Clove oils to lambs on rumen fermentation

\begin{tabular}{|c|c|c|c|c|c|}
\hline \multirow[t]{2}{*}{ Item } & \multicolumn{4}{|c|}{ Treatment $^{1}$} & \multirow[t]{2}{*}{$\mathrm{SEM}^{2}$} \\
\hline & $\begin{array}{l}\text { Control } \\
\text { group }\end{array}$ & $\begin{array}{l}\text { Anise } \\
\text { group }\end{array}$ & $\begin{array}{l}\text { Clove } \\
\text { group }\end{array}$ & $\begin{array}{l}\text { Thyme } \\
\text { group }\end{array}$ & \\
\hline $\mathrm{pH}$ value & 6.18 & 6.37 & 6.41 & 6.46 & 0.096 \\
\hline Ammonia-N concentration, $\mathrm{mg} / \mathrm{dl}$ & $17.29^{\mathrm{b}}$ & $19.13^{\mathrm{ab}}$ & $18.89^{\mathrm{ab}}$ & $20.81^{\mathrm{a}}$ & 0.685 \\
\hline Volatile fatty acid, mg/ dl & 9.606 & 10.02 & 8.91 & 9.14 & 0.369 \\
\hline
\end{tabular}




\section{El-Essawy et al.}

\section{Blood metabolites:}

Table (7) represents the effect of the three EO on some blood metabolites. The studied EO have a noticeable effect on blood plasma createnine, total lipids (TL), low density lipoprotein (LDL) and total cholesterol (TC) where they were significantly increased $(\mathrm{P}<0.05)$ in lambs given EO compared with control lambs. Garcia-Bojalil et al. (1998) suggested that oils supplementation is known to increase blood cholesterol. However, plasma levels of total protein (TP), albumin, globulin, urea, triglycerides (TG), high density lipoprotein (HDL), total antioxidant capacity, alanine aminotransferase (ALT) and aspartate

Table (7): Effect of supplementation of Anise, Thyme and Clove oils to lambs on some blood metabolites

\begin{tabular}{|c|c|c|c|c|c|}
\hline \multirow[t]{2}{*}{ Item } & \multicolumn{4}{|c|}{ Treatment $^{1}$} & \multirow[t]{2}{*}{$\mathrm{SEM}^{2}$} \\
\hline & Control & Anise & Clove & Thyme & \\
\hline Total protein, mg/dl & 7.78 & 6.98 & 6.75 & 6.66 & 0.22 \\
\hline Albumin, mg/dl & 4.36 & 3.99 & 3.78 & 4.08 & 0.28 \\
\hline Globulin, mg/dl & 3.42 & 2.99 & 2.97 & 2.58 & 0.22 \\
\hline $\mathrm{A} / \mathrm{G}$ ratio & 1.31 & 1.37 & 1.58 & 1.59 & 0.15 \\
\hline Urea, mg/dl & 55.77 & 56.34 & 46.24 & 47.79 & 2.11 \\
\hline Creatinine, mg/dl & $0.81^{\mathrm{b}}$ & $0.93^{\mathrm{ab}}$ & $1.21^{\mathrm{ab}}$ & $1.55^{\mathrm{a}}$ & 0.11 \\
\hline Triglycerides, mg/dl & 11.58 & 11.55 & 11.38 & 11.41 & 0.10 \\
\hline Total lipid, mg/l & $73.46^{\mathrm{b}}$ & $75.75^{\mathrm{ab}}$ & $76.40^{\mathrm{a}}$ & $74.80^{\mathrm{ab}}$ & 0.42 \\
\hline $\mathrm{LDL}, \mathrm{mg} / \mathrm{l}$ & $31.59^{\mathrm{c}}$ & $33.84^{\mathrm{c}}$ & $37.37^{\mathrm{b}}$ & $40.03^{\mathrm{a}}$ & 1.01 \\
\hline $\mathrm{HDL}, \mathrm{mg} / \mathrm{dl}$ & 70.63 & 71.84 & 71.05 & 70.88 & 0.41 \\
\hline Cholesterol, mg/dl & $23.23^{\mathrm{c}}$ & $21.10^{\mathrm{c}}$ & $43.30^{\mathrm{a}}$ & $36.36^{\mathrm{b}}$ & 2.06 \\
\hline Total antioxidant capacity $\mathrm{mM} / \mathrm{l}$ & 0.55 & 0.44 & 0.46 & 0.43 & 0.05 \\
\hline Alanine, $\mathrm{U} / \mathrm{l}$ & 18.33 & 15.33 & 17.67 & 18.00 & 0.97 \\
\hline Aspartate amino transferase, U/l & 13.67 & 14.33 & 17.67 & 17.67 & 0.81 \\
\hline
\end{tabular}

aminotransferase (AST) were not influenced by addition of EO. The lack of influence of EO on some blood parameters consistent with Vakili et al. (2013) who used thyme oil in diets of feedlot calves, Unal and Kocabagli (2014) with thyme in lamb ration and they found no effect on TC, TG, HDL and LDL and in another study, Khateri et. al. (2017) reported that serum TC, TP, albumin, BUN, ALT and AST concentration were not influenced by the addition of mixture of essential oils containing thyme, eugenol and cinnamon EO. Yang et al. (2010a) reported that levels of TG can be influenced by EO supply through changing of feed intake so, similar feed intake among groups in the current study contributed to similar blood levels of TG. Also, plasma creatinine concentration is reported to be a measure of muscle mass (Istasse et al., 1990) consequently, increased levels of creatinine with EO addition especially thyme or clove EO reflect the increased muscle mass in lambs of the current study and this finding is supported by the results of rib -eye area and dressing \% (Table 8). Therefore, addition of EO to lambs during the fattening period result in changes in blood metabolism that may improve production.

\section{Carcass characteristics:}

There was no effect of EO on carcass characteristics (Table 8). No statistically significant differences among groups regarding the main carcass indices such as slaughter weight, carcass weight and rib eyearea and also the chemical composition of the longissimus lumborum muscle. These results indicate the lack of influence of the anise, clove or thyme EO on the performance parameters such as feed intake and feed conversion ratio. Hence the results of performance and of the carcass are consistent with each other and with previous studies with different EO (Yang et. al. (2010b), Unal and Kocabagli, (2014), Simitzis et al. (2014) and Biricik et. al. (2016). Concerning the weight of carcass cuts, there was a significant increase with EO addition in weight of feet $(\mathrm{P}<0.05)$, full $(\mathrm{P}<0.01)$ and empty $(\mathrm{P}<0.05)$ digestive tract and tail fat $(\mathrm{P}<0.01)$ especially with clove and /or thyme addition. Besides, the weights of skin and neck tended to increase with clove or thyme addition $(\mathrm{P}=0.081$ and $\mathrm{P}=0.084$, respectively). Interestingly, lambs fed with clove, thyme or anise EO have heavier livers than those fed with control diet. Consistent with this result, Chaves et al $(2008 \mathrm{~b})$ reported heavier livers in lambs supplemented with cinnamaldehyde 
whereas Chaves et. al. (2011) found no effect of dietary supplementation with cinnamaldehyde on lamb liver. In general, addition of clove or thyme EO improved carcass cuts and organs.

Table (8): Effect of Anise, Clove and Thyme essential oils addition on carcass characteristics of major cuts, internal organs and longissimus lumborum muscle area $\left(\mathrm{cm}^{2}\right)$ and it's chemical composition of experimental lambs.

\begin{tabular}{|c|c|c|c|c|c|}
\hline \multirow[t]{2}{*}{ Item } & \multicolumn{4}{|c|}{ Treatment $^{1}$} & \multirow[t]{2}{*}{$\mathrm{SEM}^{2}$} \\
\hline & $\begin{array}{c}\text { Control } \\
\text { group }\end{array}$ & $\begin{array}{l}\text { Anise } \\
\text { group }\end{array}$ & $\begin{array}{l}\text { Clove } \\
\text { group }\end{array}$ & $\begin{array}{l}\text { Thyme } \\
\text { group }\end{array}$ & \\
\hline Slaughter weight, kg & 56.00 & 55.66 & 56.66 & 57.00 & 2.29 \\
\hline carcass weight, $\mathrm{kg}$ & 25.33 & 24.73 & 25.20 & 26.66 & 1.34 \\
\hline Dressing $\%$ & 45.23 & 44.39 & 44.52 & 46.68 & 1.12 \\
\hline Shoulder, kg & 4.34 & 4.79 & 5.03 & 5.12 & 0.336 \\
\hline Loin, $\mathrm{kg}$ & 1.971 & 2.120 & 2.688 & 2.438 & 0.224 \\
\hline Leg, $\mathrm{kg}$ & 7.303 & 8.065 & 9.214 & 9.243 & 0.614 \\
\hline Skin, kg & 7.03 & 8.32 & 9.83 & 8.33 & 0.636 \\
\hline Head, kg & 3.23 & 3.37 & 4.03 & 3.80 & 0.258 \\
\hline Feet, gm & $866.5^{\mathrm{c}}$ & $933.9^{c}$ & $1065^{\mathrm{ab}}$ & $1117.7^{\mathrm{a}}$ & 53.78 \\
\hline Digestive tract full, $\mathrm{kg}$ & $6.43^{\mathrm{b}}$ & $9.93^{\mathrm{a}}$ & $10.0^{\mathrm{a}}$ & $10.43^{\mathrm{a}}$ & 0.703 \\
\hline Digestive tract empty, $\mathrm{kg}$ & $2.97^{\mathrm{b}}$ & $3.20^{\mathrm{ab}}$ & $3.90^{\mathrm{a}}$ & $3.90^{\mathrm{a}}$ & 0.233 \\
\hline Abdominal fat,gm & 842.7 & 864.3 & 873.3 & 877.3 & 60.32 \\
\hline Kidneys fat, gm & 662 & 639 & 612.3 & 671.7 & 22.93 \\
\hline Tail fat, gm & $1005.3^{\mathrm{c}}$ & $1070^{\mathrm{b}}$ & $1163^{\mathrm{a}}$ & $1041^{\mathrm{cb}}$ & 14.79 \\
\hline 9-10-11 ribs weight, $\mathrm{Kg}$ & 1.462 & 1.483 & 1.485 & 1.543 & 57.41 \\
\hline Fat, gm & 365 & 353.3 & 366.7 & 375 & 19.82 \\
\hline Fat $\%$ & 24.96 & 24.08 & 24.91 & 24.33 & 1.97 \\
\hline Meat, gm & 750 & 798.33 & 763.3 & 800 & 52.31 \\
\hline Meat $\%$ & 51.27 & 53.53 & 51.68 & 51.84 & 2.63 \\
\hline Bone, gm & 325 & 308.3 & 303.3 & 360 & 17.71 \\
\hline Bone $\%$ & 22.22 & 21.47 & 23.14 & 23.39 & 1.05 \\
\hline Neck, kg & 1.648 & 2.476 & 2.630 & 2.861 & 0.29 \\
\hline Ribs, kg & 6.38 & 6.39 & 7.66 & 7.32 & 0.796 \\
\hline Flank, kg & 0.675 & 0.780 & 0.995 & 0.753 & 0.102 \\
\hline \multicolumn{6}{|l|}{ Internal Organs, gm } \\
\hline Lung & 634.66 & 669.63 & 694.33 & 590.30 & 79.43 \\
\hline Heart & 186.37 & 165.93 & 227.06 & 247.13 & 27.18 \\
\hline Liver & $530.26^{b}$ & $633.20^{\mathrm{ab}}$ & $782.60^{\mathrm{a}}$ & $678.03^{\mathrm{ab}}$ & 50.62 \\
\hline Spleen & 59.47 & 68.17 & 57.93 & 67.50 & 6.09 \\
\hline Kidney & 115.0 & 142.77 & 131.8 & 121.66 & 10.33 \\
\hline Tests & 363.10 & 362.06 & 409.66 & 477.10 & 51.49 \\
\hline L.L muscle area $\left(\mathrm{cm}^{2}\right)$ & 15.38 & 15.19 & 16.73 & 16.01 & 0.69 \\
\hline \multicolumn{6}{|c|}{ Chemical composition of longissimus lumborum muscle (\%) } \\
\hline Moisture & 68.55 & 67.73 & 69.76 & 68.99 & 1.41 \\
\hline Crude protein & 21.88 & 22.95 & 21.42 & 21.19 & 0.912 \\
\hline Ether extract & 6.27 & 6.37 & 6.86 & 6.70 & 0.253 \\
\hline Ash & 1.12 & 1.05 & 1.07 & 1.03 & 0.043 \\
\hline
\end{tabular}

Intramuscular fatty acid composition of longissimus lumborum muscle:

Intramuscular saturated fatty acids (SFA):

Most of intramuscular SFA were not affected by addition of EO (Table 9) except stearic acid which decreased significantly $(\mathrm{p}<0.05)$ with EO especially with clove addition. Consequently, total SFA were numerically decreased in the same group, while its value was comparable among other studied groups. Tholstrup et al. (2003) found that saturated fatty acids play an important positive role in the formation of blood cholesterol. 
Table (9): Effect of supplementation of Anise, Thyme and Clove oils to lambs on intramuscular fatty acid composition (\% of total fatty acid) of the longissimus lumborum muscle of experimental lambs.

\begin{tabular}{|c|c|c|c|c|c|}
\hline \multirow[t]{2}{*}{ Item } & \multicolumn{4}{|c|}{ Treatment $^{1}$} & \multirow[t]{2}{*}{ SEM } \\
\hline & Control & Anise & Clove & Thyme & \\
\hline \multicolumn{6}{|l|}{ SFA } \\
\hline c14, myristic & 2.03 & 2.22 & 2.12 & 2.30 & 0.16 \\
\hline c15, pentaenoic & 0.55 & 0.66 & 0.49 & 0.57 & 0.07 \\
\hline c16, palmitic & 26.27 & 26.99 & 26.78 & 27.09 & 0.60 \\
\hline c17, heptadecanoic & 2.20 & 2.06 & 2.15 & 2.20 & 0.14 \\
\hline c18, stearic & $17.44^{\mathrm{a}}$ & $16.97^{\mathrm{ab}}$ & $15.38^{\mathrm{b}}$ & $16.09^{\mathrm{ab}}$ & 0.56 \\
\hline$\sum$ SFA & 48.49 & 48.90 & 46.93 & 48.24 & 0.74 \\
\hline \multicolumn{6}{|l|}{ MUFA } \\
\hline 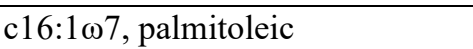 & 0.33 & 0.28 & 0.35 & 0.35 & 0.03 \\
\hline $\mathrm{C} 16: 1 \omega 5$ & $1.45^{\mathrm{c}}$ & $1.59^{\mathrm{bc}}$ & $1.99^{\mathrm{a}}$ & $1.82^{\mathrm{ab}}$ & 0.10 \\
\hline c18:1 $\omega 9$, oleic & 41.07 & 41.14 & 43.66 & 41.98 & 0.75 \\
\hline 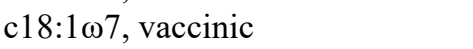 & $1.71^{\mathrm{c}}$ & $1.72^{\mathrm{c}}$ & $2.06^{\mathrm{b}}$ & $2.23^{\mathrm{a}}$ & 0.04 \\
\hline 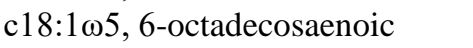 & 0.87 & 0.94 & 0.85 & 0.88 & 0.04 \\
\hline$\sum$ MUFA & $45.42^{\mathrm{b}}$ & $45.66^{\mathrm{b}}$ & $48.91^{\mathrm{a}}$ & $47.26^{\mathrm{ab}}$ & 0.70 \\
\hline \multicolumn{6}{|l|}{ PUFA } \\
\hline 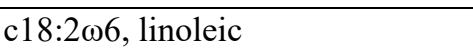 & $3.95^{\mathrm{a}}$ & $3.54^{\mathrm{ab}}$ & $2.59^{c}$ & $3.05^{\mathrm{bc}}$ & 0.16 \\
\hline 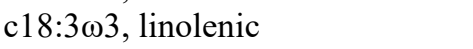 & $0.34^{\mathrm{b}}$ & $0.80^{\mathrm{a}}$ & $0.77^{\mathrm{a}}$ & $0.62^{\mathrm{a}}$ & 0.08 \\
\hline 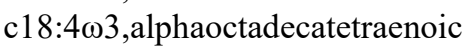 & $0.27^{\mathrm{b}}$ & $0.64^{\mathrm{a}}$ & $0.51^{\mathrm{ab}}$ & $0.37^{\mathrm{ab}}$ & 0.12 \\
\hline 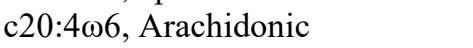 & $1.57^{\mathrm{a}}$ & $0.47^{\mathrm{b}}$ & $0.29^{\mathrm{b}}$ & $0.47^{\mathrm{b}}$ & 0.10 \\
\hline$\sum$ PUFA & $6.09^{a}$ & $5.44^{\mathrm{Ab}}$ & $4.16^{c}$ & $4.50^{\mathrm{bc}}$ & 0.31 \\
\hline$\sum$ UFA & 51.51 & 51.10 & 53.07 & 51.76 & 0.74 \\
\hline$\sum$ PUFA n-3 & $0.57^{\mathrm{b}}$ & $1.44^{\mathrm{a}}$ & $1.27^{\mathrm{a}}$ & $0.98^{\mathrm{ab}}$ & 0.14 \\
\hline$\sum$ PUFA n-6 & $5.52^{\mathrm{a}}$ & $4.00^{\mathrm{b}}$ & $2.89^{c}$ & $3.51^{\mathrm{bc}}$ & 0.24 \\
\hline \multicolumn{6}{|l|}{ Nutritional quality of meat } \\
\hline$n-6 / n-3$ & $9.77^{\mathrm{a}}$ & $2.85^{\mathrm{b}}$ & $2.27^{\mathrm{b}}$ & $3.89^{\mathrm{b}}$ & 0.50 \\
\hline PUFA/SFA & $0.13^{\mathrm{a}}$ & $0.11^{\mathrm{Ab}}$ & $0.089^{\mathrm{b}}$ & $0.093^{\mathrm{b}}$ & 0.007 \\
\hline
\end{tabular}

\section{Mono unsaturated fatty acids (MUFA):}

Only vaccinic acid was increased in thyme EO provide group followed by that of clove group while the concentration of MUFA increased significantly $(\mathrm{p}<0.05)$ in clove group followed by thyme added group. The presence of vaccinic acid which is an intermediate of bio-hydrogenation in rumen indicating incomplete bio-hydrogenation. Also El-Essawy et al. (2019) observed an increase of the unsaturated of fatty acids in milk with the same EO suggesting that EO can reduce the bio hydrogenation process resulted in improving the nutritional value of their milk consequently, benefit human health (Nudda et al., 2013).

\section{Polyunsaturated fatty acids (PUFA):}

The proportion of all omega-3 fatty acids (PUFA n-3) were increased while, all omega-6 FA ( PUFA $n-6)$ were decreased significantly $(p<0.05)$ in all EO supplied groups compared to control one which is a good indicator for healthy meat for consumer. Although the total PUFA concentration was increased in control lambs, the unsaturated fatty acids (UFA) showed insignificant changes among studied animals but clove supply increased its level numerically compared to other animals groups. Lourenco et. al. (2008) found that supplementation with cinnamaldehyde inhibited the apparent bio-hydrogenation of linoleic acid and linolenic acid. In lactating Damascus goats, Kholif et al. (2012) found that supplementation with garlic oil, cinnamon oil or ginger oil increased unsaturated FA and conjugated linoleic acid (CLA), and that cinnamon oil also increased n-3 linolenic acid. 


\section{Nutritional quality of meat:}

The $n-6 / n-3$ and PUFA/SFA ratios are used to evaluate the nutritional value of fat for human consumption. The $n-6 / n-3$ ratio is strongly dependent on the dietary FA profile fed to ruminants. Lowering the $n-6 / \mathrm{n}-3$ ratio in food production has been recommended to prevent or modulate certain human diseases, and it should range between (1-4) (WHO/FAO, 2003).

The current results indicate that $n-6 / \mathrm{n}: 3$ ratio Table (9) in muscle of lambs fed on EO were lower than 4 which is the maximum value recommended for the human diet by public health authorities, while muscle of control lambs were out of range (9.77). These results are consistent with findings of Jerónimo et al (2009), who reported that the $n-6 / n-3$ ratio in muscle of lambs was significantly decreased with sunflower oil.

Usually lamb meat has a high SFA content and low PUFA/SFA values. Increasing the PUFA concentration in the ration, by including a source rich in either $n-6$ or $n$-3 PUFA generally improves the PUFA/SFA ratio (Jerónimo et. al., 2009). The PUFA/SFA (P:S) ratio was lower than 0.45, which is the minimum value recommended for the human diet by public health authorities. This is also observed and supported in the present experiment with EO addition.

\section{CONCLUSION}

In conclusion, this study attempt to evaluate the potential use of anise, clove or thyme essential oils in fattening period of Barki lambs. Among the three essential oils, clove showed greater DM, OM, CP, EE and ADF digestibility compared with control lambs. No weight change in all experimental lambs. Also clove fed group excreted the least nitrogen resulting in increased nitrogen retention and nitrogen balance. Ammonia increased with EO addition especially clove. Overall, the results of the present study showed that the studied EO have not negative effects on growth performance and blood metabolites, meat chemical composition but improve carcass cuts weights and organs, improve FA profile of the meat providing a safer and healthier animal products for consumer. Further researches are needed with higher concentrations of EO for longer duration of supply.

\section{REFERENCES}

AOAC (2007). Official methods of analysis of AOAC international. 18th ed. Washington: Association of Official Analytical Chemists.

Benchaar, C., J. L. Duynisveld and E. Charmley (2006). Effects of monensin and increasing dose levels of a mixture of essential oil compounds on intake, digestion and growth performance of beef cattle. Canadian Journal of Animal Science., 86(1): 91-96. https://doi.org/10.4141/A05-027

Biricik, H., H. Hanoğluoral, M. A. Talug, S. S. Cengiz, M. Koyuncu and S. Dikmen (2016). The effects of carvacrol and/or thymol on the performance, blood and rumen parameters, and carcass traits of Merino sheep. J. Vet Animal Sci., 40: 651-659.

Cardozo, P.W., S. Calsamiglia, A. Ferret and C. Kamel (2004). Effect of natural plant extract on ruminal protein degradation and fermentation profiles in continuous culture. J. Animal Sci., 82:3230-3236.

Chaves, A.V, M.E.R, Dugan, K,Stanford et. al. (2011). A dose-response of cinnamaldehyde supplementation on intake, ruminal fermentation, blood metabolites, growth performance, and carcass characteristics of growing lambs. Livest Sci 2011;141:213-20.

Chaves, A.V., K. Stanford, M.E.R. Dugan, LL. Gibson, T.A. McAllister, F. Van Herk and C. Benchaar (2008a). Effects of cinnamaldehyde, garlic and juniper berry essential oils on rumen fermentation, blood metabolites, growth performance, and carcass characteristics of growing lambs. Livest. Sci., 117:215- 224 .

Chaves, A.V., K. Stanford, L.L. Gibson, T.A. McAllister and C. Benchaar (2008b). Effects of carvacrol and Cinnamaldehyde on intake, rumen fermentation, growth performance and carcass characteristics of growing lambs. Animal Feed Science and Technology., 145: 396 -408. 


\section{El-Essawy et al.}

Chowdhury, M. R., M. M. H. Khan, S. U. Mahfuz, M. A. Baset (2018). Effects of dietary supplementation of spices on forage degradability, ruminal fermentation, in vivo digestibility, growth performance and nitrogen balance in Black Bengal goat. J Anim Physiol Anim Nutr.,102:591-598.

Cieslak A., M. Szumacher-Strabel, A. Stochmal and W. Oleszek (2013). Plant components with specific activities against rumen methanogens. J. Animal., 7(s2):253-265.

Dijkstra, J., O. Oenema, J. W. van Groenigen, J. W. Spek, A. M. van Vuuren and A. Bannink (2013). Diet effects on urine composition of cattle and N2O emissions. J.Animal, 7, 292-302.

Duncan, D. B (1955). Multiple range and multiple F - tests. Biometrics., 11: 1-42.

El-Gendy, A. E. G., M. Ahmed, Abd El-Gawad, F. Rehab, Taher, A.M. Ezz El-Din, A. ElKhrisy,Elsayed, Omer, I. Abdelsamed and Elshamy (2017). Chemical diversity of essential oils from aerial parts of Cyperus capitatus L. and Cyperus difformis L. grown wild in Egypt. Journal of Essential Oil-Bearing Plants. TEOP., 20 (6): 1659 - 1665.

El-Essawy, M. Abeer, Abdou, R. Ahlam; El-Gendy, H. Marwa. (2019). Impact of Anise, Clove and Thyme essential oils as feed supplements on the productive performance and digestion of Barki ewes. Australian J. of Basic and Applied Science., 13(1): 1-13.

Fandino, I., S. Calsamiglia, A. Ferret, and M. Blanch (2008). Anise and capsicum as alternatives to monensin to modify rumen fermentation in beef heifers fed a high concentrate diet. Anim. Feed Sci. Technol., 145:409-417.

Garcia-Bojalil, C. M., C. R. Staples, C. A. Risco, J. D. Savio and w.w. Thatcher (1998). Protein degradability and calcium salts of long - chain fatty acids in the diets of lactating dairy cows: Reproductive responses. J. Dairy Sci., 81:1385 - 1395.

Goering, H.K and P.J. Van Soest (1970). Forage Fiber Analyses. Agriculture Handbook No: 379. Washington, DC, USA: ARS-USDA.

Istasse, L., C. Vaneenaeme, A. Gabriel, A. Clinquart, G. Maghuinrogister and J. M. Bienfait (1990). The relationship between carcass characteristics, plasma hormones and metabolites in young fattening bulls. Vet. Res. Commun., 14: 19-26.

Jahani-Azizabadi, H., M. Danesh Mesgaran, A.R. Vakili, K. Rezayazdi and M. Hashemi (2011). Effect of various semi-arid native medicinal plant essential oils on rumen fermentation characteristics of a high forage diet using. AFR. J. Microbiol Res., 27: 4812-9.

Jerónimo, E., S.P. Alves, J.A.M. Prates, J. Silva-Santos and R.J.B. Bessa (2009). Effect of dietary replacement of sunflower oil with linseed oil on intramuscular fatty acids for lambs meat. J. Meat Sci., 83, 499-505.

Khamisabadi, H., F. Kafilzadeh and B. Charaien (2016). Effect of thyme (Thymus vulgaris) or peppermint (Mentha piperita) on performance, digestibility and blood metabolites of fattening Sanjabi lambs. J. Biharean biologist., 10 (2): 118-122.

Khateri, N., O. Azizi and H. Jahani-Azizabadi (2017). Effects of a specific blend of essential oils on apparent nutrient digestion, rumen fermentation and rumen microbial populations in sheep fed a 50:50 alfalfa hay:concentrate diet. Asian-Australas J Anim Sci., 30 (3) :370-378.

Kholif, S.M., T.A. Morsy, Abdo, M.M. O.H. Matloup and A.A. Abu El-Ella (2012). Effect of Supplementing Lactating Goats Rations with Garlic, Cinnamon or Ginger Oils on Milk Yield, Milk Composition and Milk Fatty Acids Profile. J. Life Sci., 4(1): 27-34.

Kim, D. H., K.H. Kim, I.S. Nam, S.S. Lee, C.W. Choi, W.Y., Kim, E.G. Kwon, K.Y. Lee, M.J. Lee and Y.K. Oh (2013). Effect of indigenous herbs on growth, blood metabolites and carcass characteristics in the late fattening period of Hanwoo steers. Asian Australas. J. Anim. Sci., 26 (11): 1562 - 1568.

Lin, B., Y. Lu, A.Z.M. Salem, J.H. Wang, Q. Liang and J.X. Liu (2013). Effects of essential oil combinations on sheep ruminal fermentation and digestibility of a diet with fumarate included. Anim. Feed Sci. Technol., 184: 24-32.

Lourenco, M., P. W. Cardozo, S. Calsamiglia and V. Fievez (2008). Effects of saponnins, quercetin, eugenol and cinnamaldehyde on fatty acids bio-hydrogenation of forage polyunsaturated fatty acids in dual-flow continuous culture fermenters. J. Anim. Sci., 86:3045 - 3053. 
Moura, L.V., E.R. Oliveira, A.R.M. Fernandes, A.M.A. Gabriel, L.H.X. Silva, C.S. Takiya, N.R.B. Cônsolo, G.C.G. Rodrigues and J.R. Thaís Lemos, Gandra (2017). Feed efficiency and carcass traits of feedlot lambs supplemented either monensin or increasing doses of copaiba (Copaifera spp.) essential oil. J. Animal Feed Science and Technology., 232 (2017) :110-118.

Newbold, C.J., F.M. McIntosh, P. Williams, R. Losa, and R.J. Wallace (2004). Effects of a specific blend of essential oil compounds on rumen fermentation. J. Anim. Feed Sci. Technol., 114: 105-112.

NRC, (National Research Council) (2007). Nutrient Requirements of Small Ruminants: Sheep, Goats, Cervids, and New World Camelids. National Academy of Sciences, New York, US.

Nudda, A., G. Battacone, A.S. Atzori, C. Dimauro, S.P.G. Rassu, P. Nicolussi, P. Bonelli, and G. Pulina (2013). Effect of estrude linseed supplementation on blood metabolic profile and milk performance of Saanen goats. J. Animal., 7:1464-1471.

Santos, M.B., P.H. Robinson, P. Williams and R. Losa (2010). Effects of addition of an essential oil complex to the diet of lactating dairy cows on whole tract digestion of nutrients and productive performance. J. Animal Feed Science and Technology., 157: 64-71.

SAS (2000). Statistical analysis systems, release 8.01 Statistical analysis systems institute Inc., Cary, NC.

Sengul, T.; Yurtseven, S.; Cetin, M.; Kocyigit, A.; Sogut, B. 2008. Effect of thyme T. vulgaris extracts on fattening performance, some blood parameters, oxidative stress and DNA damage in Japanese quail. J. Anim Feed Sci., 17:608-620.

Simitzis, P. E., M. Bronis, M. A. Charismiadou. K. C. Mountzouris and S. G. Deligeorgis (2014). Effect of cinnamon (Cinnamomum zeylanicum) essential oil supplementation on lamb growth performance and meat quality characteristics. J. Animal., 8 (9):1554-1560.

Smeti, S., M. Joy, H. Hajji, J. L. Alabart, F. Munoz, M. Mahouachi, and N. Atti (2015). Effects of Rosmarinus officinalis L. essential oils supplementation on digestion, colostrum production of dairy ewes and lamb mortality and growth. J. Animal Science., 86: 679-688.

Tekippe, J.A., A.N. Hristov, K.S. Heyler, T.W. Cassidy, V.D. Zheljazkov, J.F.S. Ferreira, S.K. Karnati and G.A. Varga (2011). Rumen fermentation and production effects of Origanum vulgare L. leaves in lactating dairy cows. J. Dairy Sci., 94:5065-5079.

Terril, T.H., G.B. Douglas, A.G. Foote, R.W. Purchas, G.F. Wilson and T.N. Barry (1992). Effect of condensed tannins upon body growth, wool growth and rumen metabolism in sheep grazing sulla (Hedysarum coronarium) and perennial pasture. J. Agricultural Science., 119:265-273.

Tholstrup, T., B. Vessby and B. Sandstrom (2003). Difference in effect of myristic and stearic acid on plasma HDL cholesterol within $24 \mathrm{~h}$ in young men. European J. Clinical Nutrition., 57:735-742.

Unal, A. and N. Kocabagli (2014). Effect of different dosages of oregano oil on performance and some blood parameters in lambs. J. Ankara Univ vet Fak Deg., 61:199-204.

Vakili, A.R., B. Khorrami, M. Danesh Mesgaran and E. Parand (2013). The effects of thyme and cinnamon essential oil on performance, rumen fermentation and blood metabolites in Holstein calves consuming high concentrate diet. Asian Australas J. Anim Sci., 26:935-944.

Warner, A. C. J (1964). Production of volatial fatty acids ln the rumens methods of measurments. J. Nut. Abst. Rev., 34: 39.

WHO/FAO (World Health Organization/Food and Agriculture Organization) (2003). Diet, nutrition and the prevention of chronic diseases. Geneva, Switzerland: WHO Technical Report Series.

Williams, P., X., Cifuentes, V. Velasco, J. Campos, F. Bórquez and R. Allende (2018). Can dietary dried oregano improve the digestible nutrient intake of growing goats? Chilean J. Agric. Anim. Sci., ex Agro-Ciencia., 34(1):19-25.

Yang, W.Z, B.N. Ametaj, C. Benchaar, M.L. He and K.A. Beauchemin (2010a). Cinnamaldehyde in feedlot cattle diets: intake, growth performance, carcass characteristics, and blood metabolites. J. Anim Sci., 88: 1082-92.

Yang, W.Z., C. Benchaar, B.N. Ametaj and K. A. Beauchemin (2010b). Dose response to eugenol supplementation in growing beef cattle: ruminal fermentation and intestinal digestion. J. Animal feed science and Technology., 158:57-64. 
تأثير إضافة الزيوت العطرية للينسون و القرنفل و الزعتر علي أداء الحملان البرقي و الهضم و تخمرات الكرش الأش و صفات الأبيحة و الأحماض العطرية لإنيونة العضلية

\author{
عبير محمد عبد الحليم العيسوي1_- إبراهيم محمد عبد الحافظ خطاب_ أحلام رمضان عبده 1_ عادل محمد عبد الواحد1 \\ 1ـ شعبة الإنتاج الحيواني و الدواجن- قسم تفذية الحيوان - مركز بحوث الصحراء- المطريةـ القاهرة ـ مصر.

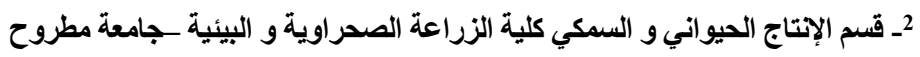

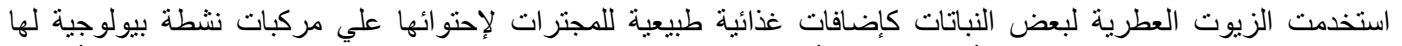

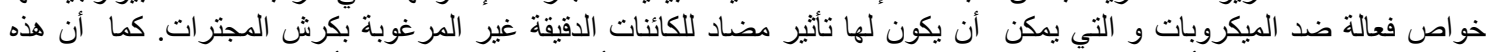

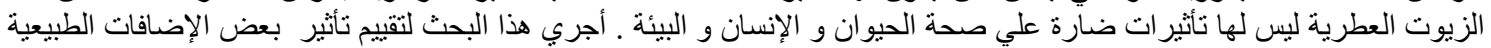

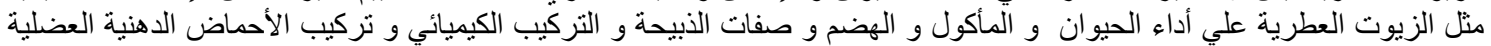

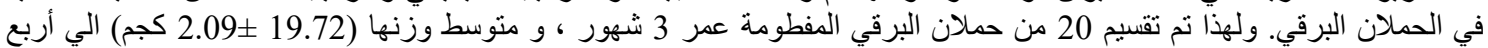

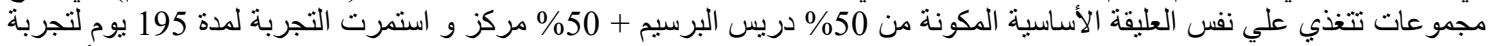

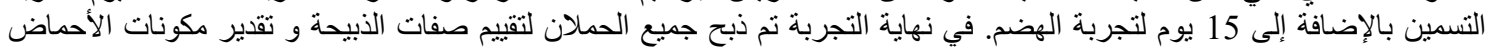

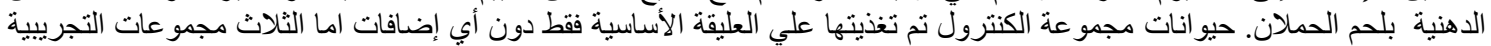

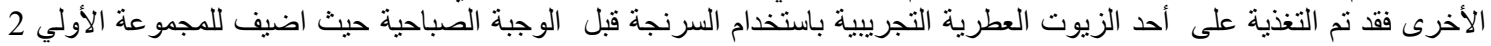

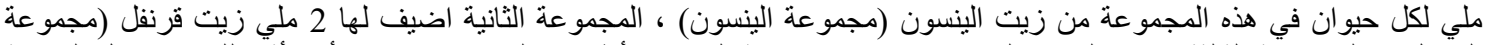

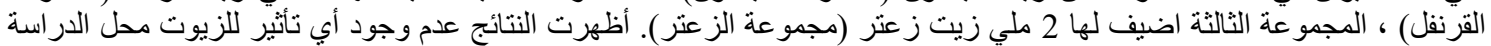

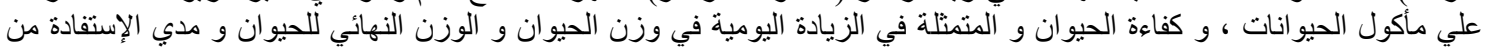

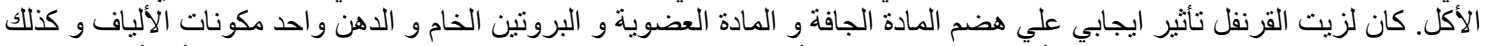

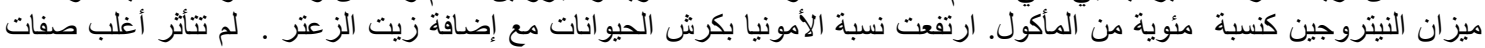

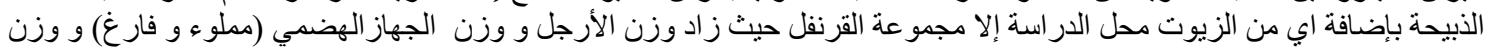

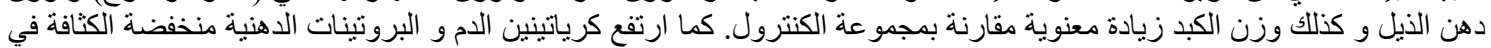

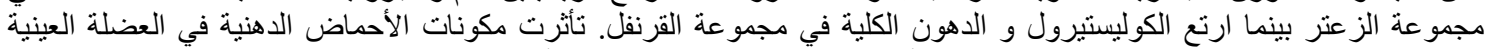

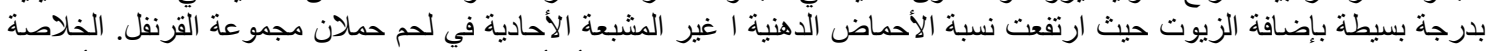

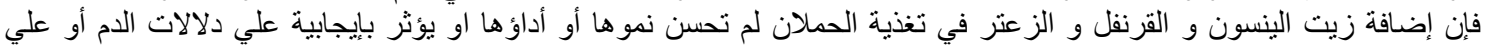

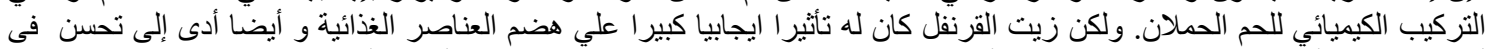

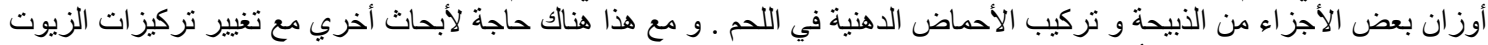
و إعطائها للحيوان لفترة الزمنية أطول. الأيحة
\end{abstract}

